\title{
Morphological and Agronomic Characteristics of Common Beans Subjected to Seed Priming With Different Doses of N6-benzyladenine
}

\author{
Ricardo A. Silva ${ }^{1}$, Sylvana N. Matsumoto ${ }^{1}$, Ramon C. Vasconcelos $^{1}$, Franklin D. Carvalho ${ }^{1}$, Luan S. Oiveira ${ }^{2}$ \\ \& Rudieli M. Silva ${ }^{2}$ \\ ${ }^{1}$ Plant and Animal Production Department, Universidade Estadual do Sudoeste da Bahia, Vitória da Conquista, \\ BA, Brazil \\ ${ }^{2}$ Production and Plant Breeding Department, Universidade Estadual Paulista Júlio de Mesquita Filho, Botucatu, \\ SP, Brazil \\ Correspondence: Ricardo A. Silva, Plant and Animal Production Department, Universidade Estadual do \\ Sudoeste da Bahia, Vitória da Conquista, BA, Brazil. Tel: 55-779-9974-8891. E-mail: \\ ricardo_deandrade@yahoo.com.br
}

Received: July 26, 2018

doi:10.5539/jas.v11n7p178
Accepted: October 3, $2018 \quad$ Online Published: May 31, 2019

URL: https://doi.org/10.5539/jas.v11n7p178

\begin{abstract}
In field conditions, the more usual application of cytokinins is based mainly on seed treatment and foliar spraying. Nowadays, seed priming with plant growth regulators is a successful agricultural practice due to its easy application in annual crops, resulting in a higher vigor and production. In order to evaluate the effect of the treatment of common bean seeds with N6-benzyladenine (6-BA), in the morphophysiology and crop yield, an experiment was carried out in a greenhouse, in a completely randomized design with four replicates and five doses of 6-BA $\left(0,0.0375,0.075,0.1125\right.$ and $0.15 \mathrm{~g} \mathrm{~kg}^{-1}$ of seed). The growth regulator was applied to the seeds in order to cover their entire surface. At 30 days after emergence, the physiological parameters were increased as a function of the doses of 6-BA. On the other hand, at 30 and 45 days after emergence of the crop, there was a drastic reduction in nodulation with increased 6-BA doses, which resulted in the lower accumulation of leaf nitrogen, pod number, and common bean yield. The ranging doses till $0.15 \mathrm{~g} \mathrm{~kg}^{-1}$ of seed of the cytokinin 6-BA are not recommended in seed priming of common beans. However, the effective recommendation of cytokinin as a seed priming is still not determined, and studies about products and doses must be improved before recommendation.
\end{abstract}

Keywords: Phaseolus vulgaris, cytokinin, bioregulators, 6-BA

\section{Introduction}

\subsection{Introduce the Problem}

Common bean is an important food of the Brazilian diet, mainly in the Northeast region of the country. However, in this region, this crop yield is considered low, due to the low level of technology used in the production systems. Therefore, the adoption of management techniques that can increase productivity, such as the use of plant growth regulators, should be evaluated.

Growth regulators are synthetic chemical compounds similar to natural plant hormones. They do not have nutritive value and, when applied in small concentrations, are able to alter metabolic and physiological processes of different plant species, such as flowering, fruiting, maturation, fruit drop, and defoliation (Rademacher, 2015). Cytokinins are a class of growth regulators that play a key role in many plant development processes, such as cell differentiation, apical dominance, leaf senescence, nutrient signaling, and chloroplast differentiation (Yeh, Chen, Ng, Lin, Tseng, Li, \& Ku, 2015).

The application of biostimulants containing cytokinin or the isolated use of the growth regulator, via foliar applications, has shown a strong tendency to increase the yield of soybean crop (Soares, Dourado Neto, Fagan, Teixeira, \& Pereira, 2017). Borges, Torres Junior, Neves, Cruvinel, Santos, and Matos (2014), when applying N6-benzyladenine (6-BA) at the end of soybean flowering, found a reduction of pod abortion, and an increase of stem diameter, the yield of components and the crop. Metivier and Paulilo (1980), when evaluating the time of 
soaking of bean seeds in 6-BA, observed an increase in embryo axis dry mass, maltose and tyrosine release, and amino acid production.

The hormones contents in a seed reserve tissue are considered a maternal legacy effect, as a memory of the environment of the previous generation, defining, sometimes, the plant vigor potential (Crisp, Ganguly, Eichten, Borevitz, \& Pogson, 2016). Interfering in this maternal memory relationship, seed priming has been applied as a way to enhance an efficient and rapid response to environmental challenges and reach a higher vigor. By this way, a cytokinin application as a seed priming to obtain a higher emergence, growth, and flowering in field conditions could be a way to reach a maximization of common bean productivity. The facility and cheaper cost of seed application when compared to foliar spraying are important factors for this choice. However, it's a fundamental importance the establishment of dose-effect ranging to reach a maximization of culture yield.

Given the above, the objective of this work was to evaluate the effects of seed priming of common bean (Phaseolus vulgaris) with 6-benzyladenina in the morphophysiology and crop yield.

\section{Materials and Methods}

The experiment was conducted at the Universidade Estadual do Sudoeste da Bahia, Campus Vitória da Conquista, from December 2015 to February 2016. The geographic coordinates of the site are $14^{\circ} 51^{\prime} 58^{\prime \prime} \mathrm{S} ; 40^{\circ} 50^{\prime} 22^{\prime \prime} \mathrm{W}$, with an average altitude of $840 \mathrm{~m}$.

The soil used was classified as Cambisol Haplic Tb Dystrophic. The soil analysis performed in August of 2015 presented the following characteristics: $\mathrm{pH}$ in $\mathrm{H}_{2} \mathrm{O}$ of $5.1 ; 1.5 \%$ of organic matter; $28 \mathrm{mg} \mathrm{dm}^{-3}$ of $\mathrm{P}\left(\mathrm{Mehlich}^{-1}\right)$; $0.2 \mathrm{cmol}_{\mathrm{c}} \mathrm{dm}^{-3}$ of K; $1.0 \mathrm{cmol}_{\mathrm{c}} \mathrm{dm}^{-3}$ of Mg; $2.5 \mathrm{cmol}_{\mathrm{c}} \mathrm{dm}^{-3}$ of $\mathrm{Ca} ; 0.1 \mathrm{cmol}_{\mathrm{c}} \mathrm{dm}^{-3}$ of Al; $4.84 \mathrm{cmol}_{\mathrm{c}} \mathrm{dm}^{-3}$ of CTC.

The experiment was conducted in a greenhouse and the soil corrected with dolomitic limestone (PRNT 80\%) in the proportion of $1080 \mathrm{~kg} \mathrm{ha}^{-1}$, aiming to raise the saturation by base to $60 \%$, applied in August 2015. In the sowing fertilization, $16 \mathrm{~kg} \mathrm{ha}^{-1}$ of N, $56 \mathrm{~kg} \mathrm{ha}^{-1}$ of $\mathrm{P}$, and $32 \mathrm{~kg} \mathrm{ha}^{-1}$ of $\mathrm{KCl}$ were applied.

The experimental design used was completely randomized design, with four replicates, each plot consisting of three $5 \mathrm{~L}$ pots, two for growth analysis and one for yield evaluation. The treatments consisted of five doses of N6-benzyladenine $\left(0,0.0375,0.075,0.1125\right.$ and $0.15 \mathrm{~g} \mathrm{~kg}^{-1}$ of seed).

\subsection{Plant Materials and Management}

The seeds were treated with the fungicide Imidacloprid + Thiodicarb $\left(425 \mathrm{~mL} \mathrm{ha}^{-1}\right)$, Co + Mo $(2.5$ and $10 \%)$ at the dose of $125 \mathrm{~mL} \mathrm{ha}^{-1}$, Bradyrhizobium tropici SEMIA 4080 inoculant $\left(100 \mathrm{~mL} \mathrm{ha}^{-1}\right)$ and 6-BA, based on sowing rate and on a population of $300,000 \mathrm{ha}^{-1}$ plants. The seeds were placed in a $2 \mathrm{~kg}$ plastic bag together with the products. Everything was agitated for 2 minutes in order to homogenize and provide uniform coverage on the surface of the seeds. Soon after homogenization, four seeds per pot were sowed, thinning the seedlings seven days after emergence (DAE), maintaining two seedlings per pot.

Irrigation was performed once a day at $8 \mathrm{~h}$ in all pots, manually with a watering can. The water replenishment was $100 \%$ of the water consumed by the crop, following a methodology proposed by Pereira et al. (2005). No cover fertilization, application of fungicides, and insecticides were applied, as cultural treatments, the weeds were removed from the pots at 10 and 20 DAE.

\subsection{Phytomass and Nitrogen Content of Common Beans Plants}

At 30 and 45 DAE, the following evaluations were performed: number of nodules, nodules were detached from the root and counted; dry mass of root and shoot, the material was oven dried with forced circulation of air, at 65 ${ }^{\circ} \mathrm{C}$ for 72 hours, and then weighed; SPAD index, obtained with portable chlorophyll meter (SPAD 502, Minolta, Japan). The electrolyte leakage following a methodology proposed by Campos and Thi (1997). For leaf nitrogen analysis, all the leaves of the plants were used, and the nitrogen determination was performed by the Kjeldahl digestion process according to the methodology described by Nogueira and Souza (2005).

Gaseous exchange evaluations (potential liquid photosynthesis, transpiration, $\mathrm{CO}_{2}$ internal concentration, and carboxylation efficiency) were measured at $30 \mathrm{DAE}$, in the third trifolium, in the base direction, using an LC-Pro open-infrared gas analyzer ADC, UK. A dichroic light source with a flux of $1000 \mu$-moles of photons $\mathrm{m}^{-2} \mathrm{~s}^{-1}$ was used.

The harvest was performed on February 28, 2016, with grain moisture between 10 and 15\%. At the same time, the number of pods per plant and yield were determined, corrected for $130 \mathrm{~g} \mathrm{~kg}^{-1}$ of moisture and determined in grams. 


\subsection{Statistical Analysis}

The obtained data were submitted to analysis of variance (Test F) and, when significant, the polynomial regression was applied through Sisvar software version 5.5.

\section{Results and Discussion}

\subsection{Physiological Characteristics}

There were effects of N6-benzyladenine doses for all studied variables, except for root dry mass and shoot dry mass at 30 DAE (Table 1).

Table 1. Summary of the variance analysis for numbers of nodule (NNOD), leaf nitrogen content (N), root dry mass (RDM), shoot dry mass (SDM), electrolyte leakage (EL) and SPAD, at 30 and 45 DAE, photosynthesis (A), transpiration $(\mathrm{E})$, internal $\mathrm{CO}_{2}$ concentration $(\mathrm{Ci})$, carboxylation efficiency $(\mathrm{A} / \mathrm{Ci})$ and number of pods $(\mathrm{NPOD})$ and yield in common bean submitted to the application of N6-benzyladenine in the treatment of seeds

\begin{tabular}{|c|c|c|c|c|c|c|c|c|c|c|}
\hline \multicolumn{11}{|c|}{ Mean Squares } \\
\hline \multirow{2}{*}{ FV } & \multirow{2}{*}{ D.F. } & \multicolumn{6}{|c|}{----------------------------------- 30 DAE ----------------------------------- } & \multicolumn{3}{|c|}{----- 45 DAE ----- } \\
\hline & & $A$ & $E$ & $\mathrm{Ci}$ & $\mathrm{A} / \mathrm{Ci}$ & EL & SPAD & EL & SPAD & \\
\hline Dose & 4 & $46.82^{* *}$ & $0.75^{* *}$ & $1155.82^{* *}$ & $0.00083^{* *}$ & $69.05^{* *}$ & $86.32^{* *}$ & $178.88^{* *}$ & $56.64^{*}$ & \\
\hline Error & 15 & 1.41 & 0.05 & 55.55 & 0.00003 & 5.60 & 5.30 & 15.59 & 14.17 & \\
\hline $\mathrm{CV}(\%)$ & & 8.29 & 9.94 & 2.52 & 10.63 & 10.91 & 6.00 & 15.09 & 11.44 & \\
\hline \multirow{2}{*}{ FV } & \multirow{2}{*}{ D.F. } & \multicolumn{3}{|c|}{------------- 30 DAE -------------- } & \multicolumn{4}{|c|}{ 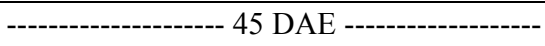 } & \multicolumn{2}{|c|}{------ 70 DAE ----- } \\
\hline & & NNOD & RDM & SDM & NNOD & RDM & SDM & $\mathrm{N}$ & NPOD & YIELD \\
\hline Dose & 4 & $35356.92^{* *}$ & $1.20^{\mathrm{ns}}$ & $4.12^{\mathrm{ns}}$ & $57308.17^{* *}$ & $9.78^{*}$ & $92.24^{*}$ & $29.78^{* *}$ & $40.49^{* *}$ & $64.41^{* *}$ \\
\hline Error & 15 & 2278.21 & 1.83 & 4.61 & 3186.55 & 3.00 & 30.00 & 0.61 & 4.33 & 10.13 \\
\hline CV $(\%)$ & & 60.38 & 19.25 & 14.57 & 75.72 & 17.12 & 17.27 & 4.48 & 21.12 & 26.20 \\
\hline
\end{tabular}

Note. ${ }^{* *}$ : significative at $1 \%(\mathrm{p}>0.01),{ }^{*}$ : significative at $5 \%(\mathrm{p}>0.05)$ and ns: no significativeby $\mathrm{F}$ test.

Potential net photosynthesis, transpiration, carboxylation efficiency, SPAD (Soil Plant Analysis Development) at 45 days after emergence (DAE), and electrolyte leakage were similarly altered as a result of increased doses of N6-benzyladenine, with quadratic polynomial models (Figures 3A, 3B, 3D, 3E, and 3F). For the internal concentration of $\mathrm{CO}_{2}$ and SPAD at $30 \mathrm{DAE}$, linear models were adjusted in response to the increase of 6-BA doses (Figures 1C and 1D). 

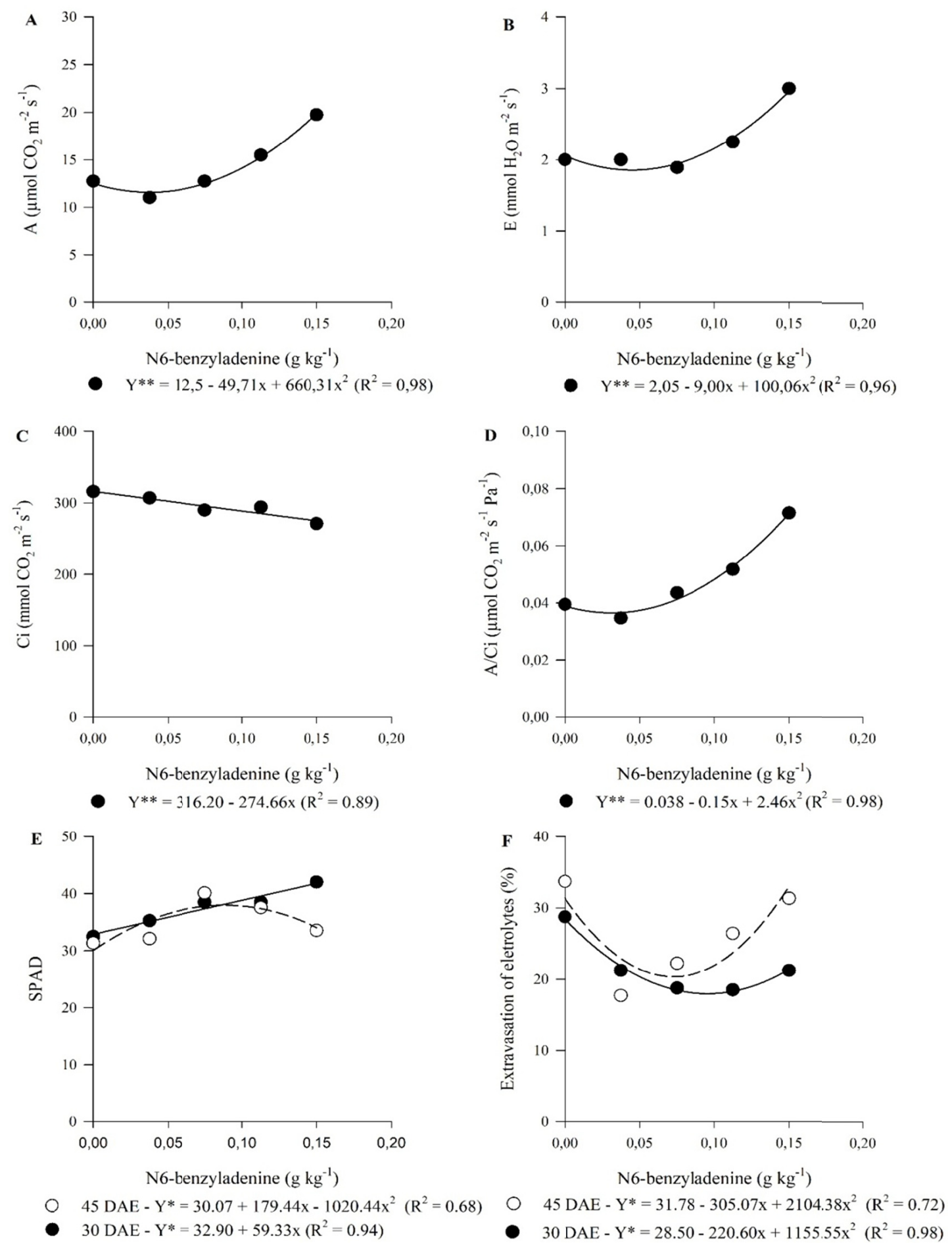

Figure 1. Potential net photosynthesis-A (A), transpiration-E (B), internal concentration of $\mathrm{CO}_{2}-\mathrm{Ci}(\mathrm{C})$, carboxylation efficiency-A/Ci (D) Electrolyte leakage-EL (E) and SPAD (F) of the bean crop submitted to the application of N6-benzyladenine in treatment of seeds

The application of 6-BA reduced the potential net photosynthesis, transpiration and, carboxylation efficiency up to the doses of $0.0376,0.0466$ and $0.0296 \mathrm{~g} \mathrm{~kg}^{-1}$ of seed, with reductions of $7.4,10.60$ and $20.51 \%$ in relation to the control treatment, respectively. However, from these points, an increase in the estimated means in the variables occurs, reaching maximum increments of $58.95,43.24$, and $89.23 \%$ for photosynthesis, transpiration, and efficiency of carboxylation, respectively, in the dose of $0.15 \mathrm{~g} \mathrm{~kg}^{-1}$ of seed in relation to the control treatment. 
For carboxylation efficiency, there is a reduction of $13.02 \%$ between the control treatment and the dose $0.15 \mathrm{~g}$ $\mathrm{kg}^{-1}$ of seed.

When studying the application of different sources of cytokinin in vitro in apple leaves, Dobránszki \& Mendler-Drienyovszki (2014) observed higher yield of the photosynthetic apparatus as a function of the type and concentration of cytokinin applied. The authors attribute this effect to the increase of chlorophyll content in the leaves and functionality of photosystem II. Xiaotao, Yuping, Hong, Haijun, Hongmei, Chunhong, and Jizhu (2013) report that N6-benzyladenine reduces the activity of antioxidant enzymes, increases the amount of chlorophyll in the leaves and the photosynthetic activity. These results corroborate with those observed in this study, where the application of 6-BA increased the parameters of gas exchange between plant and atmosphere.

The equations for electrolyte leakage generated minimum points at 0.0953 and $0.0723 \mathrm{~g} \mathrm{~kg}^{-1}$ of seed of 6-BA, at 30 and 45 DAE, respectively (Figure 1F), from these doses, the leakage elevate, however only at 45 DAE the application of N6-benzyladenine provides greater leakage of electrolytes than the treatment without application, $9.26 \%$ more at the dose of $0.15 \mathrm{~g} \mathrm{~kg}^{-1}$ of seed.

The average reduction of $35.92 \%$ verified in the minimum points for the leakage of electrolytes, represents the maintenance of the integrity of the cellular membranes. The cytokinins maintain cell membrane integrity, through the balance between cytokinin and abscisic acid (Fioreze, Rodrigues, Carneiro, Silva, \& Lima, 2013), preventing the transport of proteases from the vacuole to the cytoplasm, hydrolyzing soluble proteins of plasma membranes, chloroplasts, and mitochondria, blocking the oxidation of fatty acids and inhibiting the formation and degradation of free radicals (Soares et al., 2017).

The SPAD index is an indirect measure of the chlorophyll content in the leaf (Ertani, Schiavon, Muscolo, \& Nardi, 2013), directly related to the integrity of the cell membranes. The lower the electrolyte leakage, the greater the maintenance of chlorophyll and this can be observed with greater clarity at 45 DAE. At 30 DAE, the SPAD was $35.94 \%$ higher at the dose of $0.15 \mathrm{~g} \mathrm{~kg}^{-1}$ of seed compared to the control treatment and at 45 DAE the superiority was $26.20 \%$ at the dose of $0.0878 \mathrm{~g} \mathrm{~kg}^{-1}$ of seed, from that point the mean decreases as the 6-BA dose is elevated (Figure 1E).

Soares et al. (2017) reported that cytokinins are responsible for the increase of acid invertase activity, an enzyme responsible for catalyzing the cleavage of sucrose in hexoses which when transported to the leaves make them greener, thus raising the SPAD index.

\subsection{Phytomass and Nitrogen Content of Common Beans Plants}

The dry mass of root and dry mass of shoot were similar, without differences between treatments at 30 DAE, and it presented quadratic behavior at $45 \mathrm{DAE}$. There was a reduction in the masses, in relation to the treatment without application of N6-benzyladenine, in the order of 22.53 and $27.50 \%$ up to the minimum points verified at doses of 0.0688 and $0.0862 \mathrm{~g} \mathrm{~kg}^{-1}$ of seed, for root and shoot dry mass, respectively (Figures $2 \mathrm{~B}$ and $2 \mathrm{C}$ ). In both tendencies, there is a resumption in the increase of the masses from these doses, however, only for the dry mass of the root the values estimated reach values higher than the one verified in the control treatment, about $9.00 \%$ in the dose of $0.15 \mathrm{~g} \mathrm{~kg}^{-1}$ of seed. 
A

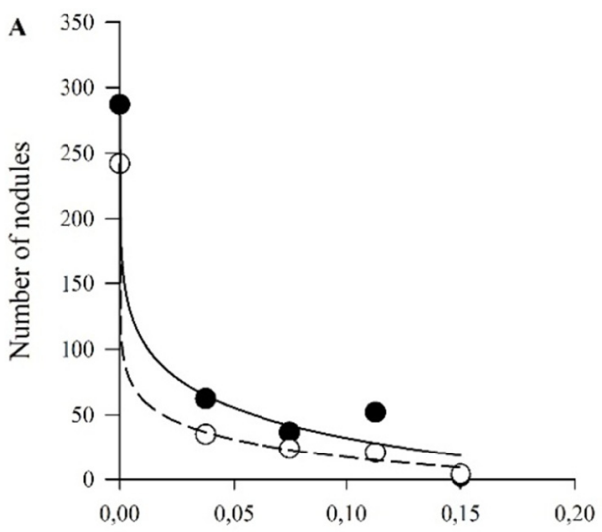

N6-benzyladenine $\left(\mathrm{g} \mathrm{kg}^{-1}\right)$

- $\left.30 \mathrm{DAE}-\mathrm{Y}^{* *}=0.021^{*} 10^{\wedge}\left((1 / \mathrm{x})^{*} \log \left(2^{(1 / 4044.21}\right)-1\right)\right)\left(\mathrm{R}^{2}=0.98\right)$

$45 \mathrm{DAE}-\mathrm{Y}^{* *}=0.013^{*} 10^{\wedge}\left((1 / \mathrm{x})^{*} \log \left(2^{(1 / 1220.95)-1)}\right)\left(\mathrm{R}^{2}=0.99\right)\right.$

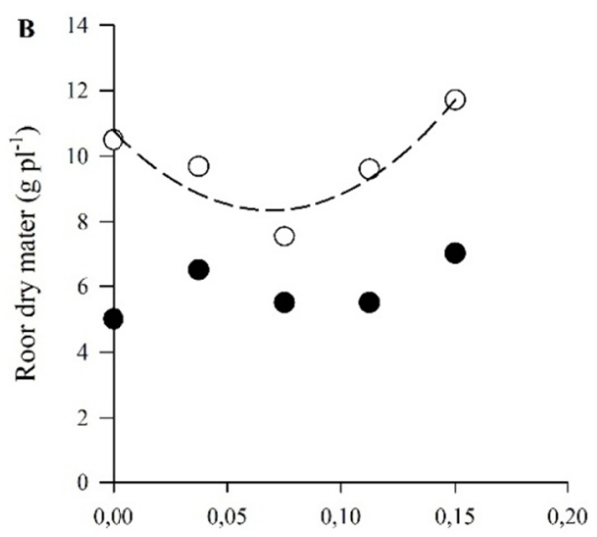

N6-benzyladenine $\left(\mathrm{g} \mathrm{kg}^{-1}\right)$

$30 \mathrm{DAE}-\mathrm{Y}=5.65$

$45 \mathrm{DAE}-\mathrm{Y}^{* *}=10.77-70.51 \mathrm{x}+167.67 \mathrm{x}^{2}\left(\mathrm{R}^{2}=0.83\right)$

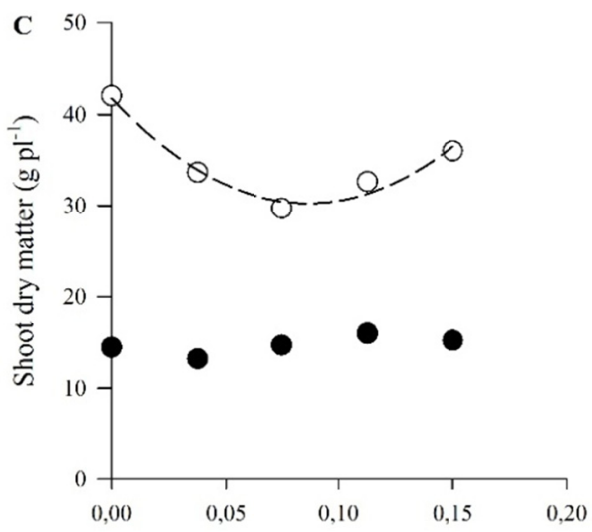

N6-benzyladenine $\left(\mathrm{g} \mathrm{kg}^{-1}\right)$

$30 \mathrm{DAE}-\mathrm{Y}=14.75$

45 DAE $-Y^{* *}=41.73-265.77 x+1540.57 x^{2}\left(R^{2}=0.96\right)$

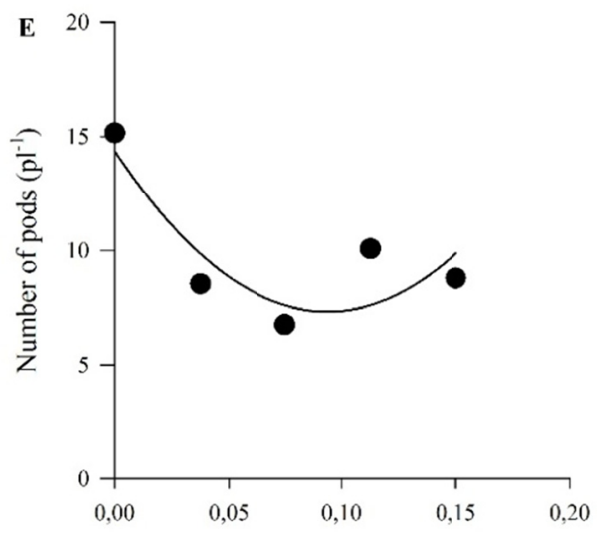

N6-benzyladenine $\left(\mathrm{g} \mathrm{kg}^{-1}\right)$

- $\mathrm{Y}^{* *}=14.35-150.25 \mathrm{x}+802.03 \mathrm{x}^{2}\left(\mathrm{R}^{2}=0.74\right)$
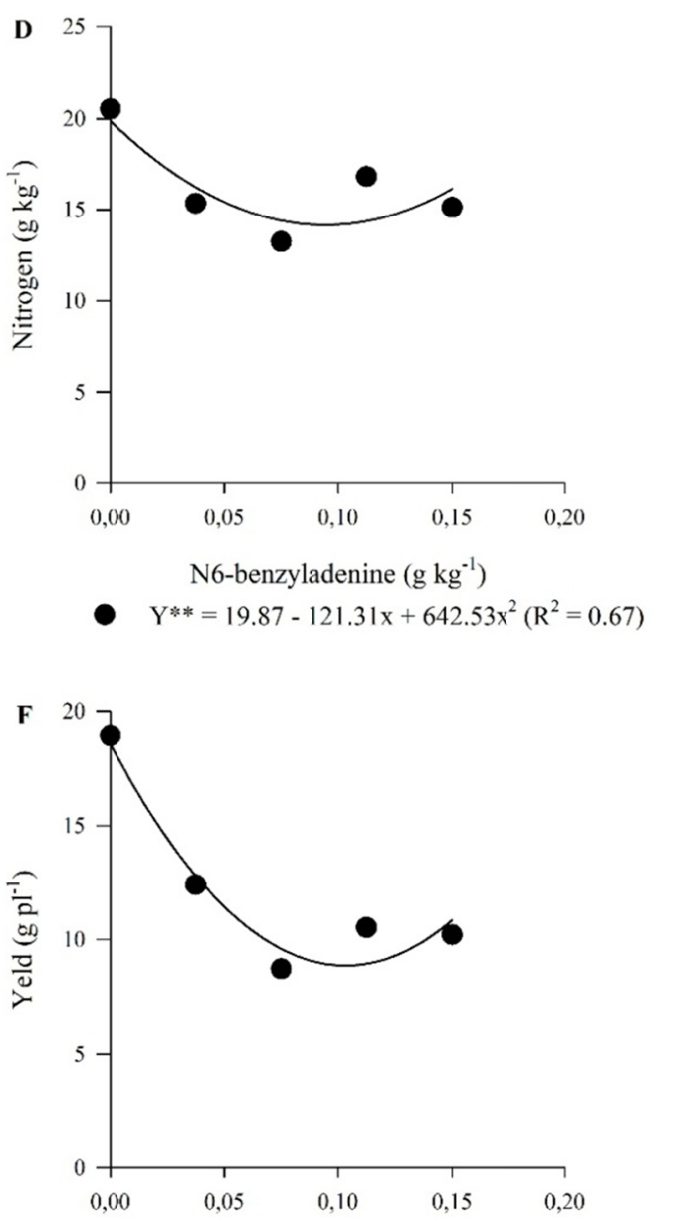

N6-benzyladenine $\left(\mathrm{g} \mathrm{kg}^{-1}\right)$

- $\mathrm{Y}^{* *}=18.58-188.51 \mathrm{x}+912.76 \mathrm{x}^{2}\left(\mathrm{R}^{2}=0.93\right)$

Figure 2. Number of nodules (A), root dry mass (B) and shoot dry mass (C) at 30 and 45 DAE, Leaf Nitrogen

(D), Number of pods (E) and yield (F) of bean crop submitted to application of N6-benzyladenine in the treatment of seeds

The reduction in root dry mass may be related to the balance between auxin and cytokinin (Machado, Pacheco, \& Carvalho, 2014). These hormones act in synergisms in the process of cell division, however, they act antagonistically in the formation of branches and in the process of root development, promoted by auxin 
(Kolling, Sangoi, Souza, Schenatto, Giordani, \& Boniatti, 2016). According to Evans (1989), the accumulation of dry matter by crops is directly linked to the availability of nitrogen and its ability to assimilate $\mathrm{CO}_{2}$ through photosynthesis.

The number of nodules presented square root response to doses of N6-benzyladenine, with a marked reduction until the doses of 3 and $7.5 \mathrm{~g} \mathrm{ha}^{-1}$, in the order of $70.00 \%$ and $95.5 \%$ at 30 and $45 \mathrm{DAE}$, respectively, from these points, at $30 \mathrm{DAE}$, there was a tendency for a decrease in the number of nodules. And at $45 \mathrm{DAE}$ there is a slight resumption in the increase in the number of nodules up to the dose of $0.15 \mathrm{~g} \mathrm{~kg}^{-1}$ of seed of 6-BA, where there is a mean reduction of $91.00 \%$ in nodulation for both evaluations (Figure $2 \mathrm{~A}$ ).

The beginning of the process of symbiosis between plant and nitrifying bacteria is dependent on the cytokinin produced by bacteria (Xu, Li, \& Luo, 2012), which in concentrations below $2.5 \times 10^{-8} \mathrm{M}$ stimulate the nodulation and in concentrations higher than $5 \times 10^{-8} \mathrm{M}$ inhibit nodulation. Therefore, the doses applied in this study were high enough to inhibit the nodulation process. Probably, the inhibition of nodulation occurs because of the high concentration of available cytokinin in the rhizosphere, thus reducing the attractiveness of the plant to establish a symbiotic relationship.

The reduction in the number of nodules had a direct effect on leaf $\mathrm{N}$ content, for which a quadratic root model was adjusted, reducing the $\mathrm{N}$ content between the control treatment and the minimum point $\left(0.0687 \mathrm{~g} \mathrm{~kg}^{-1} \mathrm{of}^{-}\right.$ seed of 6-BA) in the order of $28.84 \%$ (Figure 2D). $\mathrm{N}$ is a structural component of amino acids, proteins, chlorophyll molecule and others, which are fundamental compounds for the growth and development of plants (Fagan et al., 2007), so the reduction in their content in the plant affected directly in the production.

The SPAD index as an indirect measure of the chlorophyll content in plants allows estimating the $\mathrm{N}$ content in the leaf, as a function of the association of the nutrient with the increase in chlorophyll content in the leaf (Leonardo, Pereira, Silva, \& Costa, 2013). However, when applying high doses of 6-BA occurs intensification of green color measured by SPAD, but, this measure does not reflect the $\mathrm{N}$ content in the leaf, which reduced even with the increase in the SPAD index.

\subsection{Harvest and Yield}

The number of pods and yield of the bean crop showed a quadratic response as a function of the applied 6-BA doses. The application of 6-BA reduced the number of pods and the yield by 50.80 and $53.06 \%$., at doses of 0.0973 and $0.1048 \mathrm{~g} \mathrm{~kg}^{-1}$ of seed, respectively (Figure 2E and F).

The period of flowering and pod formation is one of the periods of higher nitrogen fixation via biological Nitrogen fixation (BNF) (Fagan et al., 2007), then, the reduction in the number of nodules and the content of leaf nitrogen were the main factors of limitation of the number of pods and yield. The hormonal imbalance may also have contributed to this result, considering that there was an increase in the physiological variables to combat stress.

Klahold, Guimarães, Echer, Klahold, Contieiro, and Becker (2006) and Albrecht, Braccini, Scapim. Ávila, and Albrecht (2012) when applying a bioregulator containing $0.009 \%$ of cytokinin in the treatment of soybean seeds, found a reduction in the crop yield at doses higher than $6 \mathrm{~mL} \mathrm{~kg}^{-1}$ of seed. Therefore, it can be inferred that when applying cytokinin in the treatment of seeds in symbiont plants with diazotrophic bacteria, although increasing plant vigor and tolerance to abiotic stresses, the ability to fix $\mathrm{N}$ is decreased, resulting in loss of yield.

\section{Conclusions}

Application of N6-benzyladenine in seed treatment reduces nodulation, shoot dry mass, electrolyte leakage and internal $\mathrm{CO}_{2}$ concentration in bean crop.

Net photosynthesis, transpiration, and efficiency of carboxylation showed a positive response to the application of N6-benzyladenine.

Application of N6-benzyladenine raises indicators of stress tolerance, in contrast, reduces the activity of biological $\mathrm{N}$ fixation, resulting in the number of pods and yield of the bean crop.

\section{References}

Albrecht, L. P., Braccini, A. L., Scapim, C, A., Ávila, M. R., \& Albrecht, A. J. P. (2012). Biorregulador na composição química e na produtividade de grãos de soja. Revista Ciência Agronômica, 43(4). https://doi.org/10.1590/S1806-66902012000400020 
Borges, L. P., Torres Junior, H. D., Neves, T. G., Cruvinel, C. K. L., Santos, P. G. F., \& Matos, F. S. (2014). Does benzyladenine application increase soybean productivity? African Journal of Agricultural Research, 9(37), 2799-2804. https://doi.org/10.5897/AJAR2014.8960

Campos, P. S., \& Thi, A. T. P. (1997). Effects of an abscisic acid pretreatment on membrane leakage and lipid composition of Vigna unguiculata leaf discs subjected to osmotic stress. Plant Science, 130(1), 11-18. https://doi.org/10.1016/S0168-9452(97)00199-4

Crisp, P. A., Ganguly, D., Eichten, S. R., Borevitz, J. O., \& Pogson, B. J. (2016). Reconsidering plant memory: Intersections between stress recovery, RNA turnover, and epigenetics. Science Advances, 2(2), 1-14. https://doi.org/10.1126/sciadv.1501340

Dobránszki, J., \& Mendler-Drienyovszki, N. (2014). Cytokinin-induced changes in the chlorophyll content and fluorescence of in vitro apple leaves. Journal of Plant Physiology, 171(1), 1472-1478. https://doi.org/ 10.1016/j.jplph.2014.06.015

Ertani, A., Schiavon, M., Muscolo, A., \& Nardi, S. (2013). Alfalfa plant-derived biostimulant stimulates short-term growth of salt stressed Zea mays L. plants. Plant and Soil, 364(1), 45-158. https://doi.org/ $10.1007 / \mathrm{s} 11104-012-1335-\mathrm{z}$

Evans, J. R. (1989). Photosynthesis and nitrogen relationships in leaves of C3 plants. Oecologia, 78(9), 9-19. https://doi.org/10.1007/BF00377192

Fagan, E. B., Medeiro, S. L. P., Manfron, P. A., Casaroli, D., Simon, J., Dourado Neto, D., ... Müller, L. (2007). Fisiologia da fixação biológica do nitrogênio em soja. Revista da FZVA, 14(1), 89-106.

Fioreze, S. L., Rodrigues, D. D., Carneiro, J. P. C., Silva, A. A., \& Lima, M. B. (2013). Fisiologia e produção da soja tratada com cinetina e cálcio sob deficit hídrico e sombreamento. Pesquisa Agropecuária Brasileira, 48(11), 1432-1439. https://doi.org/10.1590/S0100-204X2013001100003

Klahold, C. A., Guimarães, V. F., Echer, M. M., Klahold, A., Contieiro, R. L., \& Becker, A. (2006). Resposta da soja (Glycine $\max$ (L.) Merrill) à ação de bioestimulante. Acta Scientiarum Agronomy, 28(2), 179-185.

Kolling, D. F., Sangoi, L., Souza, C. A., Schenatto, D. E., Giordani, W., \& Boniatti, C. M. (2016). Tratamento de sementes com bioestimulante ao milho submetido a diferentes variabilidades na distribuição espacial das plantas. Ciencia Rural, 46(2), 248-253. https://doi.org/10.1590/0103-8478cr20150504

Leonardo, F. A. P., Pereira, W. E., Silva, S. M., \& Costa, J. P. (2013). Teor de clorofila e índice spad no abacaxizeiro cv. Vitória em função da adubação nitrogenada. Revista Brasileira de Fruticutura, 35(2), 377-383. https://doi.org/10.1590/S0100-29452013000200006

Machado, V. P. O., Pacheco, A. C., \& Carvalho, A. E. A. (2014). Effect of biostimulant application on production and flavonoid content of marigold (Calendula officinalis L.). Revista Ceres, 61(6), 983-989. https://doi.org/ 10.1590/0034-737X201461060014

Metivier, J., \& Paulilo, M. T. (1980). The utilization of cotyledonary reserves in Phaseolus vulgaris L. cv. carioca. Journal of Experimental Botany, 31(124), 1271-1282. https://doi.org/10.1093/jxb/31.5.1271

Nogueira, A. R. A., \& Souza, G. B. (2005). Manual de Laboratórios: Solo, Água, Nutrição Vegetal, Nutrição Animal e Alimentos. Retrieved from https://ainfo.cnptia.embrapa.br/digital/bitstream/CPPSE/12337/1/ ManualdeLaboratorios.pdf

Pereira, J. R. D., Carvalho, J. A., Miguel, D. S., \& Santana, M. J. (2005). Consumo de água pela cultura do crisântemo cultivada em ambiente protegido. Engenharia Agrícola, 25(3), 651-659. https://doi.org/10.1590/ S0100-69162005000300010

Pereira, H. S., Melo L. C., Faria L. C., Ferreira, E. P. B., Mercante, F. M., Wendland, A., \& Souza, T. L. P. O. (2015). Common bean elite lines cultivated under nitrogen fertilization and inoculation with Rhizobium tropici. Ciência Rural, 45(12), 2168-2173. https://doi.org/10.1590/0103-8478cr20141135

Rademacher, W. (2015). Plant growth regulators: Backgrounds and uses in plant production. Journal of Plant Growth Regulation, 34(1), 845-872. https://doi.org/10.1007/s00344-015-9541-6

Soares, L. H., Dourado Neto, D., Fagan, E. B., Teixeira, V. F., \& Pereira, I. S. (2017). Physiological, phenometric and productive changes in soybean crop due to the use of kinetin. Pesquisa Agropecuária Tropical, 47(1), 80-86. https://doi.org/10.1590/1983-40632016v4742790 
Xiaotao, D., Yuping, J., Hong, W., Haijun, J., Hongmei, Z., Chunhong, C., \& Jizhu, Y. (2013). Effects of cytokinin on photosynthetic gas exchange, chlorophyll fluorescence parameters, antioxidative system and carbohydrate accumulation in cumcumber (Cucumis sativus L.) under low light. Acta Physiologiae Plantarum, 35(1), 1224-1438.

$\mathrm{Xu}$, J., Li, X., \& Luo, L. (2012). Effects of engineered Sinorhizobium meliloti on cytokinin synthesis and tolerance of alfalfa to extreme drought stress. Applied and Environmental Microbiology, 78(22), 8056-8061. https://doi.org/10.1128/AEM.01276-12

Yeh, S., Chen, H., Ng, C., Lin, C., Tseng, T., Li, W., \& Ku, M. S. B. (2015). Down-regulation of cytokinin oxidase 2 expression increases tiller number and improves rice yield. Rice, 8(36), 1-13. https://doi.org/10.1186/ s12284-015-0070-5

\section{Copyrights}

Copyright for this article is retained by the author(s), with first publication rights granted to the journal.

This is an open-access article distributed under the terms and conditions of the Creative Commons Attribution license (http://creativecommons.org/licenses/by/4.0/). 